\title{
EFFECTS OF NITROGEN AND THREE SOIL TYPES ON MAIZE (ZEA MAYS L.) GRAIN YIELD IN NORTHEAST CHINA
}

\author{
FENG, G. Z. ${ }^{1,2}-$ WANG, Y. ${ }^{1,2}-$ YAN, L. ${ }^{1,2}-$ ZHOU, X. ${ }^{1,2}-$ WANG, S. J. ${ }^{1,2}-$ GAO, Q. ${ }^{1,2}-$ MI, G. H. ${ }^{4}$ \\ $-\mathrm{YU}, \mathrm{H} .{ }^{3 *}-\mathrm{CUI}, \mathrm{Z} . \mathrm{L}^{4^{*}}$ \\ ${ }^{1}$ College of Resources and Environmental Science, Jilin Agricultural University \\ Changchun 130118, China
}

${ }^{2}$ Key Laboratory of Soil Resource Sustainable Utilization for Jilin Province Commodity Grain Bases, Changchun, China

${ }^{3}$ College of Agriculture, Jilin Agricultural University, Changchun 130118, China

${ }^{4}$ Center for Resources, Environment and Food Security, College of Resources and Environmental Science, China Agricultural University, Beijing 100193, China

\author{
*Corresponding authors \\ e-mail: yuhan991225@126.com (Han Yu) \\ e-mail: zhenlingcui@163.com (Zhenling Cui)
}

(Received $11^{\text {th }}$ Dec 2018; accepted $27^{\text {th }}$ Feb 2019)

\begin{abstract}
The study aimed to understand the effects of nitrogen $(\mathrm{N})$ and soil types on maize (Zea mays L.). Grain yield (GY) is essential for identifying optimal $\mathrm{N}$ fertilizer management practices and agricultural policies. In this study, we report results from an on-farm experiment carried out from 2009 to 2012 with five $\mathrm{N}$ levels and three soil types in Northeast China. Results revealed that the GY was affected significantly by soil types, with loam soil having an average GY of $10225 \mathrm{~kg} \mathrm{ha}^{-1}$, followed by clay soil $\left(9218 \mathrm{~kg} \mathrm{ha}^{-1}\right)$ and sandy soil $\left(6434 \mathrm{~kg} \mathrm{ha}^{-1}\right)$. The optimal $\mathrm{N}$ rates required to achieve maximum GY were on average 182,173, and $160 \mathrm{~kg} \mathrm{ha}^{-1}$, and the corresponding maximum GYs were 10872, 9999, and 7266 $\mathrm{kg} \mathrm{ha}^{-1}$ for loam, clay, and sandy soils, respectively. The optimum $\mathrm{N}$ treatment $\left(168 \mathrm{~kg} \mathrm{~N} \mathrm{ha}^{-1}\right)$ reduced residual nitrate $\mathrm{N}$ content and $\mathrm{N}$ losses by 97 and $451 \mathrm{~kg} \mathrm{~N} \mathrm{ha}^{-1}$, respectively, and improved $\mathrm{N}$ recovery efficiency $\left(\mathrm{RE}_{\mathrm{N}}\right)$ by $17 \%$. In conclusion, within-field soil management zones based on soil textural classes could be used to guide soil sampling and establish soil-specific $\mathrm{N}$ fertilizer recommendations to achieve high GY with high $\mathrm{RE}_{\mathrm{N}}$ in Northeast China.
\end{abstract}

Keywords: maize, grain yield, nitrogen recovery efficiency, nitrogen balance, yield stability

\section{Introduction}

The global population is expected to peak at $8.5-10$ billion by 2050. Maize (Zea mays L.) grain yield (GY) must increase by $101 \%$ to feed the livestock industry given the rising meat and poultry consumption, especially in developing countries (Ray et al., 2013). Global maize GY increased slowly and then stagnated for the past 10 years (FAO, 2014), although the GY gap is large, with a 50\% GY potential. Grain yield variation among regions, climates, and management practices reduces productivity and contributes to this large GY gap (Liu et al., 2010; Zhang et al., 2013; Tesfaye et al., 2015).

For rain-fed maize production, water is one of the foremost constraints on GY which is dependent on soil water availability at sowing and on rainfall during the cropping season (Calvino et al., 2003; Gang et al., 2019). In a given region with similar climates, soil type often affects the ability to store and use rainfall, which impacts maize GY. Recent research has indicated that GY variability could be as great as $5000-6000 \mathrm{~kg} \mathrm{ha}^{-1}$, depending on the soil type and regions in Northeast China (NEC) 
(Lu et al., 2014). However, other research has reported no significant variation in GY between soil types (Tan et al., 2007; Xie et al., 2008).

Nitrogen $(\mathrm{N})$ dynamics and crop responses to $\mathrm{N}$ often vary with soil properties, climate, and management (Marjerison et al., 2016; Zhang et al., 2016; Mesbah et al., 2018; Doltra et al., 2019). For example, weather might influence organic $\mathrm{N}$ availability, the extent of leaching and denitrification, and crop uptake and residual $\mathrm{N}$ at the end of the growing season (Luce et al., 2011; Alotaibi et al., 2018; Bean et al., 2018; Iqbal et al., 2018). Soil texture is another important factor that influences soil productivity and GY by potentially controlling water supply (Cambouris et al., 2006), crop N requirements (Lu et al., 2019), and N mineralization (Luce et al., 2011; Smith, 2018). Variation in the response of maize to $\mathrm{N}$ application often leads to poor synchronization between $\mathrm{N}$ supply from the soil and fertilizer, and crop requirements resulting in low N-use efficiency (NUE) and low GY (Gao et al., 2012).

NEC is a typical rain-fed maize cultivation region in which the maize planting area was $1121 \times 10^{4}$ ha and accounted for $30.4 \%$ of the total maize crop in China in 2016 (Chinese Farming Management Department, 2017). Soil conditions, climatic factors, and weather conditions in a given year also influence GY significantly (Benjamin et al., 2003; Yao et al., 2011). A short-term effect could be inconsistent with the results of long-term observations. Agricultural research, as well as other types of research, generally involves short-term studies, but sustainable agriculture requires long-term field and laboratory experiments to understand the complex soil-plant-climatemanagement interactions (Army, 1991).

In this study, we conducted on-farm experiments with various $\mathrm{N}$ levels in three villages in close proximity $(<4 \mathrm{~km}$ apart $)$ with the same climatic conditions and differing soil types (loam, clay, and sandy soil) from 2009 to 2012 in Lishu County, Jilin Province. The objectives of this study were: (1) to evaluate GY variation among soil types and years, (2) to evaluate the GY response to $\mathrm{N}$ application rate among soil types and years to determine the optimal $\mathrm{N}$ rate for different soil types, and (3) to evaluate the soil $\mathrm{N}$ balance for different soil types.

\section{Materials and Methods}

\section{Study Site}

The climate of the study area was warm-temperate, subhumid, and continental monsoon with cold winters and hot summers. Maize was planted at the beginning of May and harvested in early October. The time from maize planting to harvest was 1400-1500 growing degree days (McMaster and Wilhelm, 1997). The annual precipitation was $500-800 \mathrm{~mm}$, with $60-70 \%$ of the rainfall occurring during the summer. No irrigation was supplied during the maize growing season. The precipitation and temperature at the experimental site during the maize growing season from 2009 to 2012 are listed in Figure 1.

\section{Experimental Design and Management}

The experiment was conducted from 2009 to 2012 on three typical soil types (loam, clay, and sandy) in Lishu County, Jilin province. These three soils were located in three nearby villages: Wang-jia-Qiao with loam soil (N43¹4'49', E124²9'10”), San-KeShu with clay soil (N43²0'17’, E12400’29”), and Fu-Jia-Jie with sandy soil 
(N43'21'48", E12405'02"; FAO 2006) (Figure 2). The distance between the three sites was $<4 \mathrm{~km}$. The physical and chemical properties of these three soil types are listed in Table 1.

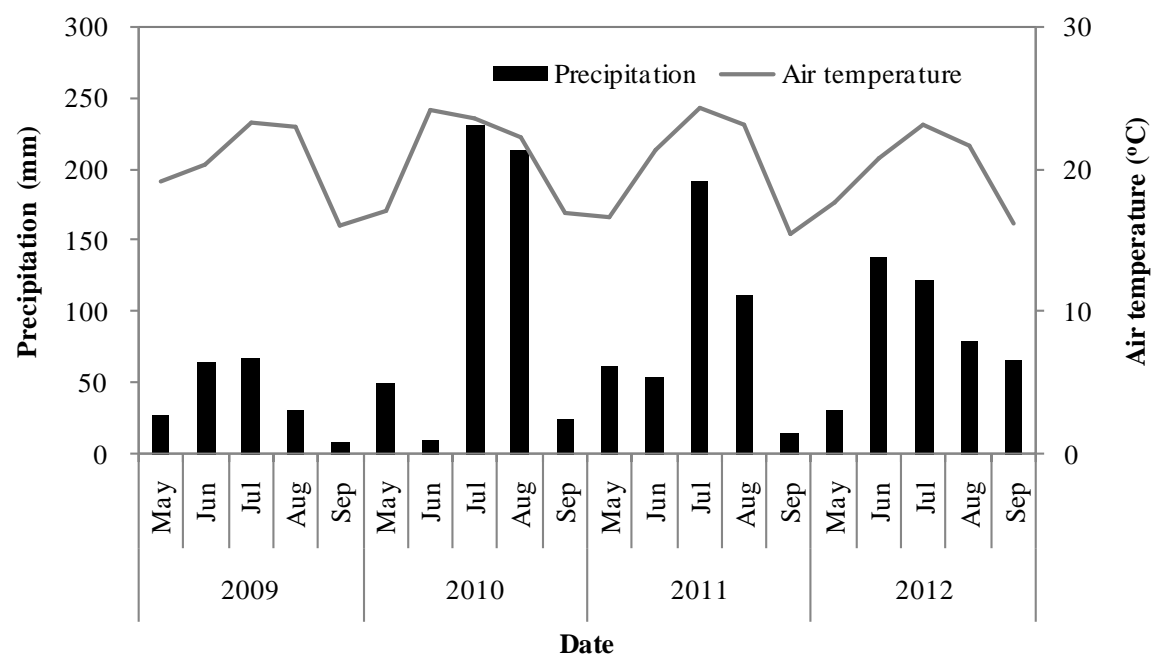

Figure 1. Precipitation and temperature at the Li-shu experimental site during the maize growing season from 2009 to 2012

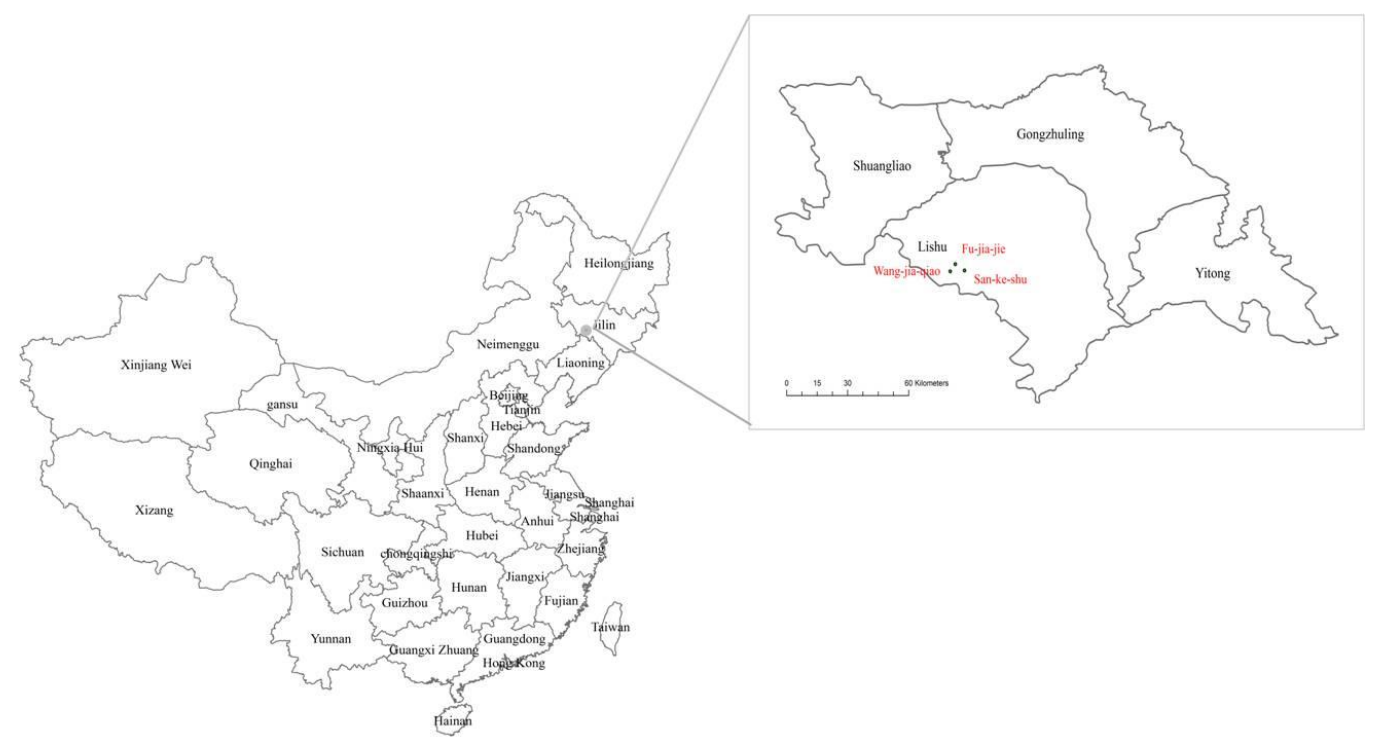

Figure 2. Distribution of experimental site in the Li-shu County, Jilin province

Table 1. Selected soil physical and chemical properties in 2009

\begin{tabular}{c|c|c|c|c|c|c|c|c}
\hline Locations & Texture & $\begin{array}{c}\text { Bulk density } \\
\left(\mathbf{m g ~ m}^{-3}\right)\end{array}$ & $\begin{array}{c}\text { Organic } \\
\mathbf{m a t t e r} \\
\left(\mathbf{g k g}^{-1}\right)\end{array}$ & $\begin{array}{c}\text { Total N } \\
\left(\mathbf{g k g}^{-1}\right)\end{array}$ & $\mathbf{p H}$ & $\begin{array}{c}\text { NaOH-N } \\
\left(\mathbf{g k g}^{-1}\right)\end{array}$ & $\begin{array}{c}\text { Olsen-P } \\
\left(\mathbf{g k g}^{-1}\right)\end{array}$ & $\begin{array}{c}\mathbf{N H 4 O A c - K} \\
\left(\mathbf{g k g}^{-1}\right)\end{array}$ \\
\hline Wang-Jia-Qiao & clay loam & 1.32 & 12.2 & 1.04 & 5.15 & 91.6 & 29.1 & 52 \\
San-Ke-Shu & loamy clay & 1.42 & 25.3 & 1.69 & 6.16 & 128.2 & 43.9 & 122 \\
Fu-Jia-Jie & sandy loam & 1.51 & 13.2 & 1.01 & 6.71 & 58.8 & 13.6 & 43 \\
\hline
\end{tabular}


For the three soil types, the experiments from 2009 to 2012 were designed as a randomized block with three replicates of five nitrogen $(\mathrm{N})$ treatments were as follows: control (N0), 70\% recommendation $\mathrm{N}$ rate $(\mathrm{N} 168)$, recommendation $\mathrm{N}$ rate based on local government recommend fertilization $(\mathrm{N} 240), 130 \%$ recommendation $\mathrm{N}$ rate (N312), and the typical $\mathrm{N}$ dose used by farmers (N270). The $\mathrm{N}$ application rates were as follows: 0, 168, 240, 270, and $312 \mathrm{~kg} \mathrm{~N}^{-1}$ applied as urea. All $\mathrm{N}$ fertilizer was granular urea with one-third applied before planting and the remaining two-thirds applied at the V8 stage. All plots received $100 \mathrm{~kg}_{2} \mathrm{O}_{5} \mathrm{ha}^{-1}$ as calcium superphosphate and $120 \mathrm{~kg} \mathrm{~K}_{2} \mathrm{O}$ ha $^{-1}$ as $\mathrm{K}_{2} \mathrm{SO}_{4}$ before planting.

The plot size was $60 \mathrm{~m}^{2}(6 \times 10 \mathrm{~m})$. Maize was planted continuously from 2009 to 2012. The planting density was 65,000 plants ha ${ }^{-1}$ with a row spacing of $60 \mathrm{~cm}$. Seeds of the XY335 cultivar were hand-sown on May 5, 8, 5, and 4 during 2009, 2010, 2011, and 2012, respectively. The maize was rain-fed and harvested on October 5 during each of the four years. Weeds were controlled by applying atrazine and acetochlor before seedling emergence, and no obvious pest stress was observed during the maize growing season.

\section{Sampling and Laboratory Procedures}

At physiological maturity, when more than $50 \%$ of the plants showed a visible black layer at the base of the kernel, plants were removed manually from an area of $18 \mathrm{~m}^{2}$ (six rows, approximately $3.6-\mathrm{m}$ wide $\times 5$-m long) in the middle of each plot to measure GY. Plant samples were taken at harvest. Aboveground biomass was collected by clipping five plants in three rows near the middle of each plot to measure plant dry matter weight and $\mathrm{N}$ concentration. Plants were divided into grain and straw. All plant samples were dried at $70^{\circ} \mathrm{C}$ in a forced-draft oven to constant weight and then weighed. Subsamples were passed through a 1-mm screen in a sample mill and mineralized using $\mathrm{H}_{2} \mathrm{SO}_{4}-\mathrm{H}_{2} \mathrm{O}_{2}$, after which the $\mathrm{N}$ concentration was determined using the Kjeldahl method (Horowitz et al., 1970).

At least five soil samples were taken in every plot to a depth of $100 \mathrm{~cm}$ at $20-\mathrm{cm}$ increments before planting and after harvest. Fresh soil samples were sieved, extracted with $0.01 \mathrm{~mol} \mathrm{~L}^{-1} \mathrm{CaCl}_{2}$ solution and $\mathrm{NH}_{4}{ }^{+}-\mathrm{N}$ and $\mathrm{NO}_{3}{ }^{-}-\mathrm{N}$ were analyzed by continuous flow analysis (TRAACS2000; Bran + Luebbe, Norderstedt, Germany) in the laboratory. Soil water content was measured by oven drying at $105^{\circ} \mathrm{C}$. Soil samples were collected at the $0-20-\mathrm{cm}$ soil layer before planting, air-dried, and sieved through a $0.2-\mathrm{mm}$ mesh to remove undecomposed plant materials. The sieved samples were used to measure organic material $(\mathrm{OM})$, total $\mathrm{N}$, Olsen-P, and $\mathrm{NH}_{4} \mathrm{OAc}-\mathrm{K}$.

\section{Data Analysis}

After verifying the homogeneity of error variances, all of the data across soil types, $\mathrm{N}$ levels, and years were pooled for analysis of variance using the ANOVA procedure of SAS/STAT (SAS Institute, 1993). Differences were compared using the least significant difference test (LSD) at the 0.05 level of probability.

Three response models were evaluated to describe the relationship between $\mathrm{N}$ application and GY: quadratic, quadratic with a plateau, and linear with a plateau (Cerrato and Blackmer, 1990). The models were generated using SAS software (SAS Institute, 1993). The calculated optimum $\mathrm{N}$ rate for $\mathrm{GY}$ was given with a $95 \%$ confidence interval. 
The increase in GY with applied $\mathrm{N}$ fertilizer $\left(\mathrm{IY} \mathrm{Y}_{\mathrm{N}}\right)$ was defined as the difference between the maximum GY and the GY of the zero-N (N0) treatment for each experiment. The agronomic $\mathrm{N}$ efficiency $\left(\mathrm{AE} \mathrm{N}_{\mathrm{N}}\right)$ and $\mathrm{N}$ partial factor productivity $\left(\mathrm{PFP}_{\mathrm{N}}\right)$ were calculated using equations (1) and (2) below (Ladha et al., 2005). AE $\mathrm{E}_{\mathrm{N}}$ was the GY increase per unit of $\mathrm{N}$ applied, and $\mathrm{PFP}_{\mathrm{N}}$ was the most important index for farmers since it integrates the use efficiency of both indigenous and applied $\mathrm{N}$ resources.

$$
\begin{gathered}
\mathrm{AE}_{\mathrm{N}}=\left(\mathrm{Y}_{\mathrm{N}}-\mathrm{Y}_{0}\right) / \mathrm{N} \\
\mathrm{PFP}_{\mathrm{N}}=\mathrm{Y}_{\mathrm{N}} / \mathrm{N}
\end{gathered}
$$

where $\mathrm{Y}_{\mathrm{N}}$ and $\mathrm{Y}_{0}$ are $\mathrm{GY}$ values for $\mathrm{N}$ application plots and $\mathrm{N}_{0}$ plots, respectively, and $\mathrm{N}$ is supplied by the applied fertilizer.

\section{Results}

\section{Grain YieldVariance among Soil Types and Years}

Considering all four years and five $\mathrm{N}$ treatments, GY was affected significantly by soil type (Table 2). The rank order of the GYs for the three soil types was loam > clay > sandy soil with GY values of 10225, 9218, and $6434 \mathrm{~kg} \mathrm{ha}^{-1}$, respectively (Table 2).

Table 2. Analysis of variance of maize grain yield, ear number, grain number, and 100 grain

\begin{tabular}{|c|c|c|c|c|}
\hline Treatments & Yield $\left(\mathrm{kg} \mathrm{ha}^{-1}\right)$ & Earnumber $\left(\mathrm{ha}^{-1}\right)$ & Grain number (ear-1) & 100 Grain weight (g) \\
\hline \multicolumn{5}{|l|}{ Soil } \\
\hline Loam soil & $10225 a$ & $58951 \mathrm{a}$ & $522.6 \mathrm{a}$ & $33.3 \mathrm{a}$ \\
\hline Clay soil & $9218 b$ & $54942 b$ & $526.3 \mathrm{a}$ & $31.6 b$ \\
\hline Sandy soil & $6434 c$ & $49251 \mathrm{c}$ & $398.7 b$ & $28.9 \mathrm{c}$ \\
\hline \multicolumn{5}{|l|}{ Year } \\
\hline 2009 & $7276 c$ & $48787 d$ & $421.9 \mathrm{c}$ & $30.2 \mathrm{c}$ \\
\hline 2010 & $9522 a$ & $56287 \mathrm{~b}$ & $513.8 \mathrm{a}$ & $33.0 \mathrm{a}$ \\
\hline 2011 & $8366 b$ & $54119 \mathrm{c}$ & $515.8 \mathrm{a}$ & $29.8 c$ \\
\hline 2012 & $9339 a$ & $58330 \mathrm{a}$ & $478.5 b$ & $32.0 \mathrm{~b}$ \\
\hline \multicolumn{5}{|l|}{ Nitrogen } \\
\hline 0 & $5732 \mathrm{c}$ & $51938 b$ & $389.8 \mathrm{c}$ & $26.9 b$ \\
\hline 168 & $9257 b$ & $55019 \mathrm{a}$ & $492.1 b$ & $32.5 \mathrm{a}$ \\
\hline 240 & $9554 a$ & $54827 \mathrm{a}$ & $516.6 \mathrm{a}$ & $32.4 \mathrm{a}$ \\
\hline 270 & 9379ab & $55262 \mathrm{a}$ & $505.0 \mathrm{ab}$ & $32.3 \mathrm{a}$ \\
\hline 312 & $9207 b$ & $54859 \mathrm{a}$ & $509.1 \mathrm{ab}$ & $32.2 \mathrm{a}$ \\
\hline \multicolumn{5}{|c|}{ Source of variation } \\
\hline Soil(S) & $* *$ & $* *$ & $* *$ & $* *$ \\
\hline Year (Y) & $* *$ & $* *$ & $* *$ & $* *$ \\
\hline Nitrogen $(\mathrm{N})$ & $* *$ & $* *$ & $* *$ & $* *$ \\
\hline $\mathrm{Y} \times \mathrm{S}$ & $* *$ & $* *$ & $* *$ & $* *$ \\
\hline $\mathrm{Y} \times \mathrm{N}$ & $* *$ & $* *$ & $* *$ & $* *$ \\
\hline $\mathrm{S} \times \mathrm{N}$ & $* *$ & NS & $* *$ & NS \\
\hline $\mathrm{Y} \times \mathrm{S} \times \mathrm{N}$ & $* *$ & $*$ & $* *$ & NS \\
\hline
\end{tabular}
weight for various nitrogen treatments in three soil types across 4 years

Within soil, nitrogen or year, numbers followed by different letters indicate significant differences $(P<$ $0.05)$.

NS: not significant $(P>0.05)$.

*Significant at $P<0.05$.

**Significant at $P<0.01$ 
Plant density was uniform for all three soil types. The numbers of ears at maturity were significantly different with a rank order of loam $>$ clay $>$ sandy soil (Table 2). Similar results were obtained for 100 grain weight among the soils, with a rank order of loam > clay > sandy soil. The grain number was essentially the same for the loam (523 per ear) and clay (526 per ear) soils, which were approximately $31.6 \%$ higher than the 399 grains per ear for sandy soil (Table 2).

Considering all three soil types and the five $\mathrm{N}$ treatments, GY was affected significantly by year (Table 2). The highest GYs were observed in 2010 and 2012, which might be explained by greater precipitation during those years $(583$ and $437 \mathrm{~mm}$ for 2010 and 2012, respectively; Fig. 1). The lowest GY in 2009 might be explained by rainfall during the maize growth period of only $207 \mathrm{~mm}$ and drought during the flowering and early grain filling stages between July and August (Fig. 1). Meanwhile, the average GYs in the loam and clay soils were 9574 and $10142 \mathrm{~kg} \mathrm{ha}^{-1}$, respectively, which were significantly higher than the GY in sandy soil (981 kg ha ${ }^{-1}$, Fig. 3).

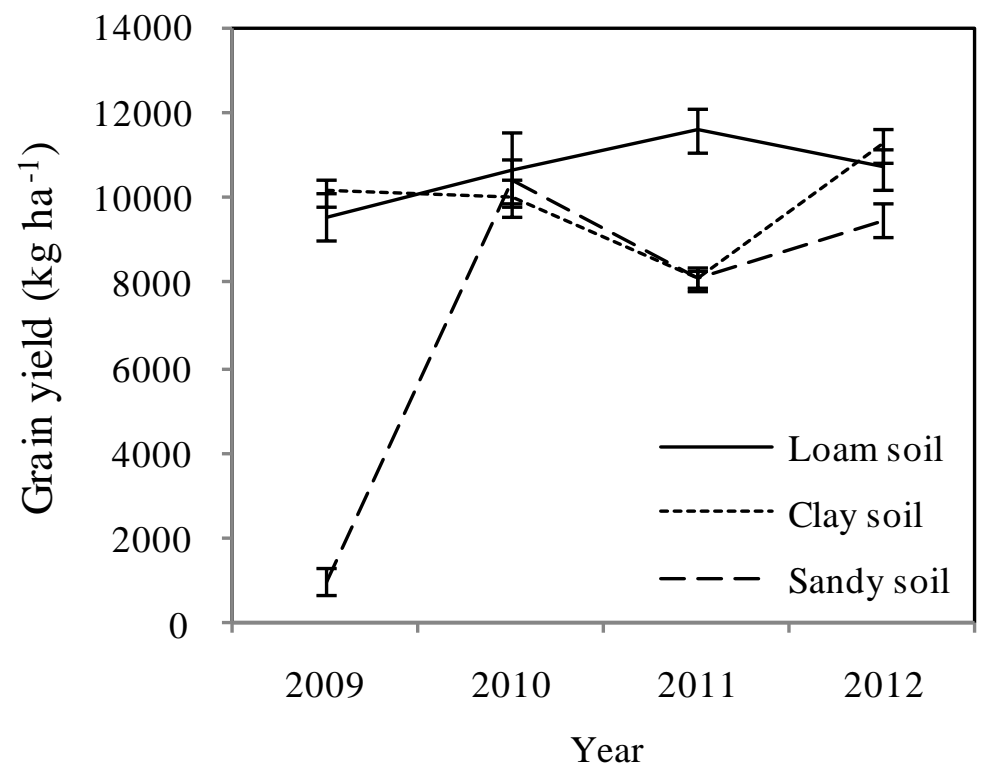

Figure 3. Yield stability in three soil types with under optimal nitrogen application. Data were pooled across four years $(n=36)$

The low GY in 2011 might have been due to lodging between July 30 and August 1 . Due to different lodging rates among the three soil types, with a rank order of clay $>$ loam > sandy soil and values of 29.2, 13.1, and 8.2\%, respectively (Table 3), the GY for clay and sandy soils averaged 8089 and $8126 \mathrm{~kg} \mathrm{ha}^{-1}$, respectively, which was significantly less than the GY in loam soil $\left(11600 \mathrm{~kg} \mathrm{ha}^{-1}\right.$; Fig. 3).

The effect of year $\times$ soil interaction on GY was significant, indicating that the effects of soil on GY differed among years. During the four years (2009-2012), GYs for the N168 treatment in the loam, clay, and sandy soils averaged $10638 \mathrm{~kg} \mathrm{ha}^{-1}$ with a range of $8960-12021 \mathrm{~kg} \mathrm{ha}^{-1}, 9882 \mathrm{~kg} \mathrm{ha}^{-1}$ with a range of $7861-11713 \mathrm{~kg} \mathrm{ha}^{-1}$, and $7252 \mathrm{~kg} \mathrm{ha}^{-1}$ with a range of 695-10913 $\mathrm{kg} \mathrm{ha}^{-1}$, respectively (Fig. 3). 
Table 3. Analysis of variance of lodging rates for three soil types under nitrogen application in 2011

\begin{tabular}{c|c|c|c}
\hline \multirow{2}{*}{ Treatments } & \multicolumn{3}{|c}{ Soil type } \\
\cline { 2 - 4 } & Loam soil & Clay soil & Sandy soil \\
\hline N0 & $3.7 \mathrm{c}$ & $9.1 \mathrm{c}$ & $1.4 \mathrm{e}$ \\
N168 & $11.1 \mathrm{~b}$ & $24.6 \mathrm{~b}$ & $4.7 \mathrm{~d}$ \\
N240 & $12.0 \mathrm{~b}$ & $25.5 \mathrm{~b}$ & $8.5 \mathrm{c}$ \\
N270 & $12.9 \mathrm{~b}$ & $29.6 \mathrm{~b}$ & $11.7 \mathrm{~b}$ \\
N312 & $25.6 \mathrm{a}$ & $57.3 \mathrm{a}$ & $14.7 \mathrm{a}$ \\
\hline
\end{tabular}

Means followed by the same lowercase letter within a column for a given year are not significantly different

\section{Grain Yield Response to N Application Rate among Soil Types and Years}

Grain yield response to increasing $\mathrm{N}$ rate differed among the soil types and years as indicated by a significant soil type $\times$ year $\times \mathrm{N}$ interaction effect. A linear-plateau $\mathrm{GY}$ response to increasing $\mathrm{N}$ rate was the most appropriate model for the three soil types. Across the four years, the optimal $\mathrm{N}$ rate required to achieve maximum $\mathrm{GY}$ averaged 182, 173, and $160 \mathrm{~kg} \mathrm{ha}^{-1}$ for loam, clay, and sandy soils, respectively. The corresponding maximum GYs for loam, clay, and sandy soils were 10872, 9999, and $7266 \mathrm{~kg} \mathrm{ha}^{-1}$, respectively.

The GY in loam soil increased quadratically with increasing $\mathrm{N}$ rate in 2010, while a linear-plateau model was most appropriate for 2009, 2011, and 2012. The minimum $\mathrm{N}$ rates needed to achieve maximum GY were 270, 180, 150, and $186 \mathrm{~kg} \mathrm{ha}^{-1}$ for 2009 (Fig. 4a), 2010 (Fig. 4d), 2011 (Fig. 4g), and 2012 (Fig. 4j), respectively. Grain yields for the N0 rate were 8810, 9560, 6538, and $6397 \mathrm{~kg} \mathrm{ha}^{-1}$ in 2009 (Fig. 4a), 2010 (Fig. 4d), 2011 (Fig. 4g), and 2012 (Fig. 4j), respectively.

Similar results were observed for clay soil during the experiment years. The linearplateau GY responses to $\mathrm{N}$ were the most appropriate models for clay soil (Fig. 4). Grain yield increased from $9539 \mathrm{~kg} \mathrm{ha}^{-1}$ for the N0 rate to a maximum GY of $10521 \mathrm{~kg} \mathrm{ha}^{-1}$ obtained with $320 \mathrm{~kg} \mathrm{~N} \mathrm{ha}^{-1}$ in 2009 (Fig. 4b). Maximum GYs for 2010 (Fig. 4e), 2011 (Fig. 4h), and 2012 (Fig. 4k) were 10148, 8241, and $11256 \mathrm{~kg} \mathrm{ha}^{-1}$, respectively, at minimum $\mathrm{N}$ rates of 175,174 , and $155 \mathrm{~kg} \mathrm{~N} \mathrm{ha}^{-1}$, respectively.

A linear-plateau GY response to increasing $\mathrm{N}$ rate was the most appropriate model for the sandy soil from 2010 to 2012, while there was no relationship in 2009 (Fig. 4c). The minimum $\mathrm{N}$ rates needed to achieve maximum $\mathrm{GY}$ were 158,90 , and $175 \mathrm{~kg} \mathrm{ha}^{-1}$ for 2010 (Fig. 4f), 2011 (Fig. 4i), and 2012 (Fig. 4l), respectively. Maximum GYs for 2010, 2011, and 2012 were 9944,8108 , and $9829 \mathrm{~kg} \mathrm{ha}^{-1}$, respectively. Grain yields for the N0 rate in 2010 (Fig. 4f), 2011 (Fig. 4i), and 2012 (Fig. 4l) were 4296, 5387, and $1272 \mathrm{~kg} \mathrm{ha}^{-1}$, respectively.

Under drought conditions in 2009 (206 $\mathrm{mm}$ rainfall during the maize growing season) (Fig. 1), a linear-plateau GY response to increasing $\mathrm{N}$ rate was the most appropriate model for the loam (Fig. 4a) and clay soils (Fig. 4b), while there was no relationship in sandy soil (Fig. $4 c$ ). The total rainfall values during the maize growing seasons in 2010 and 2012 were 583.2 and $437.2 \mathrm{~mm}$, respectively, which were greater than for 2009 (Fig. 1). Despite the relatively small GY for the N0 rate in sandy soil, the maximum GY in sandy soil (9944 and $9829 \mathrm{~kg} \mathrm{ha}^{-1}$ for 2010 and 2012, respectively) 
was similar to the maximum GY observed for loam soil (10428 and $11170 \mathrm{~kg} \mathrm{ha}^{-1}$ for 2010 and 2012, respectively) and clay soil (10148 and $11256 \mathrm{~kg} \mathrm{ha}^{-1}$ for 2010 and 2012, respectively).

Across the experiment years, the optimal $\mathrm{N}$ rate required to achieve maximum $\mathrm{GY}$ was $160-180 \mathrm{~kg} \mathrm{ha}^{-1}$ for the three soil types. The $\mathrm{PFP}_{\mathrm{N}}$ ranged from 57.0 to $69.0 \mathrm{~kg} \mathrm{~kg}^{-1}$ in loam soil and from 48.0 to $67.1 \mathrm{~kg} \mathrm{~kg}^{-1}$ in clay soil. In contrast, the $\mathrm{PFP}_{\mathrm{N}}$ ranged from 5.8 to $61.9 \mathrm{~kg} \mathrm{~kg}^{-1}$ in sandy soil, indicating that $\mathrm{N}$ efficiencies in loam and clay soils were stable compared with sandy soil, for which the $\mathrm{PFP}_{\mathrm{N}}$ of $5.8 \mathrm{~kg} \mathrm{~kg}^{-1}$ was affected by drought in 2009.
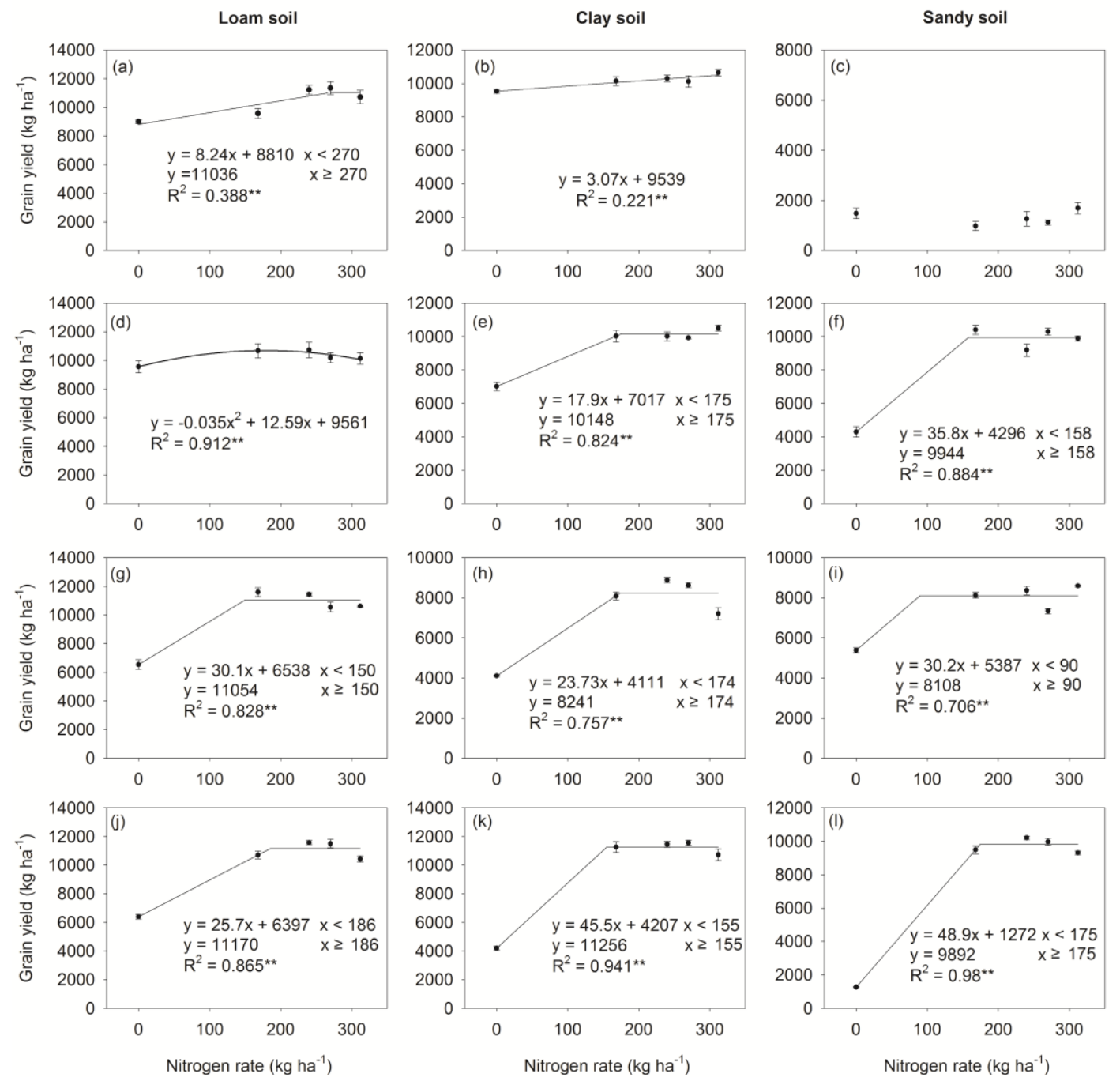

Figure 4. Effects of nitrogen application on grain yield (at $14 \%$ moisture) on loam (left), clay (middle), and sandy soils (right) from 2009 to 2012

Considering all four years and three soil types, GY was affected significantly by $\mathrm{N}$ treatments. Nitrogen fertilizer increased the maize GY significantly, with the GYs of the N168, N240, N270, and N312 treatments increased by 3525 (62\%), 3822 (67\%), 3647 (64\%), and $3475 \mathrm{~kg} \mathrm{ha}^{-1}(61 \%)$, respectively, compared with the N0 control $(P<0.05$, Table 2). Compared with the N312 treatment, the N240 treatment increased the maize 
GY significantly (347 $\left.\mathrm{kg} \mathrm{ha}^{-1}, P<0.05\right)$, despite applying an average of $72 \mathrm{~kg}$ less $\mathrm{N}$ $\mathrm{ha}^{-1}$. The average maize $\mathrm{N}$ uptake was affected significantly by the $\mathrm{N}$ treatments. The average maize $\mathrm{N}$ uptake values for the $\mathrm{N} 240$, N270, and N312 treatments were 178, 178 , and $176 \mathrm{~kg} \mathrm{ha}^{-1}$, respectively, which were significantly higher than for the N0 and N168 treatments (100 and $169 \mathrm{~kg} \mathrm{ha}^{-1}$, respectively). The average $\mathrm{PFP}_{\mathrm{N}}$ was affected significantly by the $\mathrm{N}$ treatments with a rank order of N312 < N270 < N240 < N168 and values of $30,35,40$, and $55 \mathrm{~kg} \mathrm{~kg}^{-1}$, respectively (Table 4).

Table 4. Analysis of variance of nitrogen partial factor productivity $\left(P F P_{N}\right)$ and agronomic efficiency $\left(A E_{N}\right)$ on three soil types across four years

\begin{tabular}{c|c|c}
\hline Treatments & $\mathbf{P F P}_{\mathbf{N}}\left(\mathbf{k g ~ k g}^{-\mathbf{1}}\right)$ & $\mathbf{A E}_{\mathbf{N}}\left(\mathbf{k g ~ k g}^{-\mathbf{1}}\right)$ \\
\hline Soil & & \\
Loam soil & $46.0 \mathrm{a}$ & $12.5 \mathrm{c}$ \\
Clay soil & $42.4 \mathrm{~b}$ & $16.0 \mathrm{~b}$ \\
Sandy soil & $30.9 \mathrm{c}$ & $17.7 \mathrm{a}$ \\
Nitrogen & & \\
168 & $55.1 \mathrm{a}$ & $21.0 \mathrm{a}$ \\
240 & $39.8 \mathrm{~b}$ & $15.9 \mathrm{~b}$ \\
270 & $34.7 \mathrm{c}$ & $13.5 \mathrm{c}$ \\
312 & $29.5 \mathrm{~d}$ & $11.1 \mathrm{~d}$ \\
Source of variation & $* *$ & $* *$ \\
Soil(S) & $* *$ & $* *$ \\
Nitrogen(N) & $* *$ & $\mathrm{~ns}$ \\
S $\times \mathrm{N}$ & & \\
\hline
\end{tabular}

Within soil, nitrogen, numbers followed by different letters indicate significant differences $(P<0.05)$.

NS: not significant $(P>0.05)$.

* Significant at $P<0.05$.

** Significant at $P<0.01$

\section{Residual Nitrate- $N$ and Soil $N$ Balance}

Across the experiment years (2009-2012), residual minimum soil $\mathrm{N}_{\min }$ data showed an average of $87.2 \mathrm{~kg} \mathrm{~N}^{-1}$ with a range of 61.7 to $126.8 \mathrm{~kg} \mathrm{~N} \mathrm{ha}^{-1}$ and an average of $183.7 \mathrm{~kg} \mathrm{~N} \mathrm{ha}^{-1}$ with a range from 76.5 to $321.3 \mathrm{~kg} \mathrm{~N} \mathrm{ha}^{-1}$ in the $0-100-\mathrm{cm}$ soil profile for the N168 and N312 treatments, respectively, after harvest (Table 5). Presumably, some of the residual soil $\mathrm{N}_{\min }$ would be subject to environmental loss, particularly in the period after maize harvest. Soil types affected the residual soil $\mathrm{N}_{\min }$ significantly, with residual soil $\mathrm{N}_{\min }$ in the $0-100-\mathrm{cm}$ soil layer of clay soil being significantly higher than that in the loam and sandy soils (Table 5). Compared to sandy soil (73.2 and $76.5 \mathrm{~kg}$ $\mathrm{N} \mathrm{ha}^{-1}$ for the $\mathrm{N} 168$ and $\mathrm{N} 312$ treatments, respectively) and loam soil (61.7 and $153.4 \mathrm{~kg} \mathrm{~N} \mathrm{ha}{ }^{-1}$ for the $\mathrm{N} 168$ and $\mathrm{N} 312$ treatments, respectively), more residual soil nitrate- $\mathrm{N}$ was present in clay soil (126.8 and $321.3 \mathrm{~kg} \mathrm{~N} \mathrm{ha}^{-1}$ for the N168 and N312 treatments, respectively). Similar results were observed for residual soil $\mathrm{NO}_{3}{ }^{-} \mathrm{N}$ in the $0-100-\mathrm{cm}$ soil layer. The residual soil $\mathrm{NO}_{3}{ }^{-}-\mathrm{N}$ in the $0-100-\mathrm{cm}$ soil layer in sandy soil was $26.0 \mathrm{~kg} \mathrm{ha}^{-1}$ as compared with 74.2 and $57.2 \mathrm{~kg} \mathrm{ha}^{-1}$ for clay and loam soils, respectively. We attributed these differences to soilfertility and soil texture in addition to high soil silt and clay content (Table 1).

The calculated total apparent $\mathrm{N}$ losses across the experiment years (2009-2012) ranged from 315 to $481 \mathrm{~kg} \mathrm{~N} \mathrm{ha}^{-1}$ with a mean of $372 \mathrm{~kg} \mathrm{~N} \mathrm{ha}^{-1}$ and from 678 to $965 \mathrm{~kg}$ $\mathrm{N} \mathrm{ha}{ }^{-1}$ with a mean of $823 \mathrm{~kg} \mathrm{~N} \mathrm{ha}^{-1}$ for the N168 and N312 treatments, respectively 
(Table 5). The calculated total apparent $\mathrm{N}$ losses across the experiment years were affected significantly by the soil type. The calculated total apparent $\mathrm{N}$ losses in loam and sandy soils increased to 965 and $827 \mathrm{~kg} \mathrm{~N} \mathrm{ha}^{-1}$, respectively, compared with $678 \mathrm{~kg}$ $\mathrm{N} \mathrm{ha}^{-1}$ in clay soil for the $\mathrm{N} 312$ treatment.

Table 5. Calculated $N$ balances for three soil types from 2009-2012 $\left(\mathrm{kg} \mathrm{N} \mathrm{ha}^{-1}\right)$

\begin{tabular}{|c|c|c|c|c|c|c|c|c|c|}
\hline \multirow{2}{*}{ Treatments } & \multicolumn{3}{|c|}{ No } & \multicolumn{3}{|c|}{ N168 } & \multicolumn{3}{|c|}{ N312 } \\
\hline & Loam & Clay & Sandy & Loam & Clay & Sandy & Loam & Clay & Sandy \\
\hline $\begin{array}{c}\text { Overall summary } \\
(2009-2012) \\
\text { A. N Input }\end{array}$ & & & & & & & & & \\
\hline 1. $\mathrm{N}$ fertilizer & 0 & 0 & 0 & 672 & 672 & 672 & 1248 & 1248 & 1248 \\
\hline $\begin{array}{l}\text { 2. } 0-100 \mathrm{~cm} \mathrm{~N} \mathrm{~min} \\
\text { before sowing }\end{array}$ & $222.4 \mathrm{a}$ & $178.3 \mathrm{a}$ & $70.0 \mathrm{~b}$ & $222.4 \mathrm{a}$ & $178.3 \mathrm{a}$ & $70.0 \mathrm{~b}$ & $222.4 \mathrm{a}$ & $178.3 \mathrm{a}$ & $70.0 \mathrm{~b}$ \\
\hline $\begin{array}{l}\text { 3. Apparent } \mathrm{N} \\
\text { mineralization } \dagger\end{array}$ & $447.9 \mathrm{a}$ & $328.1 \mathrm{~b}$ & $146.3 \mathrm{c}$ & $447.9 \mathrm{a}$ & $328.1 \mathrm{~b}$ & $146.3 \mathrm{c}$ & $447.9 \mathrm{a}$ & $328.1 b$ & $146.3 \mathrm{c}$ \\
\hline $\begin{array}{l}\text { Total input: } 1+2+3 \\
\text { B. N output }\end{array}$ & $670.3 a$ & $506.4 \mathrm{~b}$ & $216.3 \mathrm{c}$ & $1342.3 \mathrm{a}$ & $1178.4 \mathrm{~b}$ & $888.3 \mathrm{c}$ & $1918.3 \mathrm{a}$ & $1754.4 \mathrm{~b}$ & $1464.3 \mathrm{c}$ \\
\hline $\begin{array}{l}\text { 4. N removed by grain } \\
\text { and straw }\end{array}$ & $616.1 \mathrm{a}$ & $409.6 \mathrm{~b}$ & $178.7 \mathrm{c}$ & 799.1a & $731.7 \mathrm{a}$ & $500.0 \mathrm{~b}$ & $800.4 \mathrm{a}$ & $755.3 \mathrm{a}$ & $561.1 \mathrm{~b}$ \\
\hline $\begin{array}{c}\text { 5. 0-100 cm N min after } \\
\text { harvest }\end{array}$ & $54.2 \mathrm{~b}$ & $96.8 \mathrm{a}$ & $37.6 \mathrm{c}$ & $61.7 b$ & $126.8 \mathrm{a}$ & $73.2 b$ & $153.4 b$ & $321.3 \mathrm{a}$ & $76.5 \mathrm{c}$ \\
\hline Total output: $4+5$ & $670.3 a$ & $506.4 \mathrm{~b}$ & $216.3 \mathrm{c}$ & $860.9 \mathrm{a}$ & $858.5 \mathrm{a}$ & $573.2 \mathrm{~b}$ & $953.7 b$ & $1076.6 \mathrm{a}$ & $637.6 \mathrm{c}$ \\
\hline Apparent $\mathrm{N}$ losses & & & & $481.4 \mathrm{a}$ & $319.9 b$ & $315.0 \mathrm{~b}$ & $964.6 \mathrm{a}$ & $677.8 b$ & $826.7 \mathrm{a}$ \\
\hline $\begin{array}{c}\text { Nitrogen-use efficiency } \\
(\%)\end{array}$ & & & & $27.2 b$ & $47.9 \mathrm{a}$ & $47.8 \mathrm{a}$ & $14.8 \mathrm{~b}$ & $27.7 \mathrm{a}$ & $30.6 \mathrm{a}$ \\
\hline
\end{tabular}

$\uparrow$ Apparent $\mathrm{N}$ mineralization was calculated as the difference between the $\mathrm{N}$ output (plant $\mathrm{N}$ uptake plus residual soil $\mathrm{Nmin}$ ) and the $\mathrm{N}$ input (initial soil $\mathrm{Nmin}$ in0-100cm soil layers) in no $\mathrm{N}$ treatment (Meisinger, 1984).

\$ Apparent $\mathrm{N}$ losses were calculated as the difference between the $\mathrm{N}$ input (initial soil Nmin plus apparent $\mathrm{N}$ mineralization and $\mathrm{N}$ fertilizer) and the $\mathrm{N}$ output(plant $\mathrm{N}$ uptake plus residual soil $\mathrm{Nmin}$ ) in $\mathrm{N}$-applied treatments (Zhao et al., 2006).

$\S \mathrm{N}$ recovery $=(\mathrm{N}$ uptake in $\mathrm{N}$ fertilization plot $-\mathrm{N}$ uptake in no $\mathrm{N}$ fertilization plot $) /$ the amount of $\mathrm{N}$ fertilizer $\times 100$.

*Different letters indicate significant difference at $P=0.05$.

Considering all four years and the three soil types, $\mathrm{RE}_{\mathrm{N}}$ was affected significantly by the $\mathrm{N}$ treatments compared with the $\mathrm{N} 312$ treatment. $\mathrm{RE}_{\mathrm{N}}$ for the N168 treatment increased significantly by $17 \%$, from 24 to $41 \%$ (Table 5). The soil types affected $R_{N}$ significantly for loam soil (27.2 and $14.8 \%$ for N168 and N312, respectively) and RE was higher in clay soil (48 and 28\% for N168 and N312, respectively) and sandy soil (48 and 31\% for N168 and N312, respectively).

\section{Discussion}

Across the experimental years, grain yield was significantly affected by soil types, especially in 2009 and 2011. In 2009, the rainfall during the maize growth period was only $207 \mathrm{~mm}$, and there was a drought in May and early grain filling stage (Fig. 1). Drought in seedling stage affected emergence resulted lower seedling emerge rate (Fu et al., 2008), drought stress in flowering and early grain filling stage limited photosynthesis and reduced the flux of assimilates to the developing ears and filling 
grain (Saini and Westgate, 2000; Beyene et al., 2016; Tao et al., 2016; Kim et al., 2017), and the higher evaporation on sandy soil (Lu et al., 2014), which resulted lower ear number and 100 grain weight, further decreased the GY in sandy soil (Table 2). Due to differing degrees of drought vulnerability of the loam, clay, and sandy soils (Egamberdiyeva, 2007), the average GYs in the loam and clay soils were significantly higher than the GY in sandy soil (Fig. 3). Root lodging can reduce harvestable yield of many crops including maize (Brune et al., 2018). Root lodging tends to be associated with environmental factors such as heavy rains coinciding with wind (Farkhari et al., 2013), such as in 2011, there was a heavy rain $(80.7 \mathrm{~mm})$ with wind in July $30-31$. Higher lodging rate in clay soil might be explained by a plow pan which prevent the root grow into deep soil (He, 2006; Qin, 2008).

Grain yield for the zero-N treatment in loam soil, clay soil and sandy soil averaged 7873,6216 and $3110 \mathrm{~kg} \mathrm{ha}^{-1}$ respectively, indicated that greater soil $\mathrm{N}$ availability supply contributed to greater GY. Additional soil characteristics, especially soil texture (Ziadi et al., 2013), soil water content (Cambouris et al., 2006), and $\mathrm{N}$ mineralization (Luce et al., 2011; Smith, 2018), appeared to have contributed to variation in soil $\mathrm{N}$ availability, soil productivity and yield potential among in-field location (Tolk et al., 1999).

In general, sandy soil had lower productivity due to lower soil fertility (soil organic matter content), nutrient preserved capability and water retaining capacity, compared with loam and clay soil (Egamberdiyeva, 2007). Such as in 2012, grain yield for the zero-N treatment in sandy soil averaged $1272 \mathrm{~kg} \mathrm{ha}^{-1}$, which was significantly lower than that in loam soil $\left(6397 \mathrm{~kg} \mathrm{ha}^{-1}\right)$ and clay soil $\left(4206 \mathrm{~kg} \mathrm{ha}^{-1}\right)$. The grain yield stability in loam and clay soil soil is significantly higher than that in sandy soil, the coefficients of variation for GY over the four years were 7.8, 13.4, and 59.1\% for the loam, clay, and sandy soils, respectively.

In rain-fed maize system, yield response to $\mathrm{N}$ fertilizer may various, which has been attributed to differences in soil $\mathrm{N}$ supply, $\mathrm{N}$ use efficiency, and environments (Meisinger, 1984; Lory and Scharf, 2003). In this study, the GY response to nitrogen was various among the three soil type. The linear-plateau model of GY response to increasing $\mathrm{N}$ rate was showed that maximum $\mathrm{GY}$ of three soil type followed by loam soil $\left(10872 \mathrm{~kg} \mathrm{ha}^{-1}\right)>$ clay soil $\left(9999 \mathrm{~kg} \mathrm{ha}^{-1}\right)>$ sandy soil $\left(7266 \mathrm{~kg} \mathrm{ha}^{-1}\right)$. However, the $\mathrm{IY}_{\mathrm{N}}$ followed by sandy soil $\left(4156 \mathrm{~kg} \mathrm{ha}^{-1}\right)>$ clay soil $\left(3783 \mathrm{~kg} \mathrm{ha}^{-1}\right)>$ loam soil $\left(2999 \mathrm{~kg} \mathrm{ha}^{-1}\right)$. Across the experimental years, the optimal $\mathrm{N}$ rate required to achieve the maximum GY maintained $160-180 \mathrm{~kg} \mathrm{ha}^{-1}$ for the three soil types. Nitrogen partial factor productivity maintained from 57.0 to $69.0 \mathrm{~kg} \mathrm{~kg}^{-1}$ in loam soil, from 48.0 to $67.1 \mathrm{~kg} \mathrm{~kg}^{-1}$ in clay soil. In contrast, the nitrogen partial factor productivityvaried from 5.8 to $61.9 \mathrm{~kg} \mathrm{~kg}^{-1}$ in sandy soil, indicated that nitrogen efficiency in loam soil and clay soil were stable compared with sandy soil, such as nitrogen partial factor productivity just $5.8 \mathrm{~kg} \mathrm{~kg}^{-1}$ affected by drought in 2009 .

To achieve satisfactory agronomic performance while minimizing negative environmental impact, $\mathrm{N}$ fertilization recommendations must consider the dynamics between $\mathrm{N}$ supply from the soil and $\mathrm{N}$ demand by the crops (Ayoub et al., 1995; Cassman et al., 2002; Cui et al., 2009). However, in China, pursuing high grain yield has been the top priority in policy and in practice. The typical $\mathrm{N}$ rate applied by maize farmers in the Northeast China (NEC) is excess (Chen et al., 2014). As expected, the $\mathrm{RE}_{\mathrm{N}}$ in Northeast China maize production systems is low, the potential environmental impact from over fertilization and low $\mathrm{N}$ recovery can be substantial. In this study, the 
optimum $\mathrm{N}$ treatment (N168) reduced residual nitrate $\mathrm{N}$ content in the top 100-cm soil layer and $\mathrm{N}$ losses by 97 and $451 \mathrm{~kg} \mathrm{~N} \mathrm{ha}^{-1}$, respectively, compared with the excessive $\mathrm{N}$ treatment (N312).

In the current corn production system, the big difference in $\mathrm{IY}_{\mathrm{N}}$ (increased yield for applied $\mathrm{N}$ fertilizer) was attributed to the differences among soil types, suggesting that soil type led to a high degree of field-to-field variability in the yield response to applied $\mathrm{N}$ fertilizer. Consequently, the big challenge is how to reduce variation among different soil types and decrease yield gaps.

\section{Conclusions}

The challenge of meeting food demand in China during the next 50 years must be met by simultaneously increasing GY and NUE; however, the rain-fed maize GY differed among soil types, indicating a conflict between high GY and improved NUE under current maize production practices. An improved fundamental understanding of GY and NUE in response to management practices and soil types is needed to rectify this situation. Our study demonstrated that higher GY was obtained in loam and clay soils compared to sandy soil, which implies that recommended $\mathrm{N}$ fertilizer rates need to be adjusted and take into account soil type. Across the four years, the optimal $\mathrm{N}$ rates required to achieve the maximum GY averaged 182, 173, and $160 \mathrm{~kg} \mathrm{ha}^{-1}$ for loam, clay, and sandy soils, respectively. The corresponding maximumGYs for loam, clay, and sandy soils were 10872,9999 , and $7266 \mathrm{k} \mathrm{g} \mathrm{ha}^{-1}$, respectively. The $\mathrm{PFP}_{\mathrm{N}}$ averaged 46.0, 42.4, and $30.9 \mathrm{~kg} \mathrm{~kg}^{-1}$ for loam, clay, and sandy soils, respectively. The average $\mathrm{RE}_{\mathrm{N}}, \mathrm{AE}_{\mathrm{N}}$, and $\mathrm{PFP}_{\mathrm{N}}$ values under the optimum $\mathrm{N}$ treatment (N168) were $41 \%$, $21 \mathrm{~kg} \mathrm{~kg}^{-1}$, and $55 \mathrm{~kg} \mathrm{~kg}^{-1}$, respectively, which were all significantly higher than for $\mathrm{N} 312\left(\mathrm{RE}_{\mathrm{N}}, 24 \% ; \mathrm{AE}_{\mathrm{N}}, 11 \mathrm{~kg} \mathrm{~kg}^{-1}\right.$; and $\left.\mathrm{PFP}_{\mathrm{N}}, 30 \mathrm{~kg} \mathrm{~kg}^{-1}\right)$. As a result, the optimum $\mathrm{N}$ treatment (N168) reduced residual nitrate $\mathrm{N}$ content in the top 100-cm soil layer and $\mathrm{N}$ losses by 97 and $451 \mathrm{~kg} \mathrm{~N} \mathrm{ha}^{-1}$, respectively, compared withthe excessive $\mathrm{N}$ treatment (N312). Such knowledge could be used todevelop robust $\mathrm{N}$ management practices to provide effective $\mathrm{N}$ management practice recommendations over a wide range of soilclimate combinations.

Acknowledgements. This study was supported by the National Key Research and Development Program of China (2017YFD0201801).

\section{REFERENCES}

[1] Alotaibi, K. D., Cambouris, A. N., Luce, M., Ziadi, N., Tremblay, N. (2018): Economic Optimum Nitrogen Fertilizer Rate and Residual Soil Nitrate as Influenced by Soil Texture in Corn Production. - Agronomy Journal 110: 1-10.

[2] Army, T. J. (1991): Support for long-term agricultural research. - Agronomy Journal 83(1): 62-65.

[3] Ayoub, M., Mackenzie, A., Smith, D. L. (1995): Evaluation of N fertilizer rate and timing and wheat cultivars on soil residual nitrates. - Journal of Agronomy and Crop Science 175(2): 87-97.

[4] Bean, G. M., Kitchen, N. R., Camberato, J. J., Ferguson, R. B., Fernandez, F. G., Franzen, D. W., Schepers, J. (2018): Improving an active-optical reflectance sensor algorithm using soil and weather information. - Agronomy Journal 110: 1-11. 
[5] Benjamin, J. G., Nielsen, D. C., Vigil, M. F. (2003): Quantifying effects of soil conditions on plant growth and crop production. - Geoderma 116(1-2): 137-148.

[6] Beyene, Y., Semagn, K., Crossa, J., Mugo, S., Atlin, G. N., Tarekegne, A., Alvarado, G. (2016): Improving maize grain yield under drought stress and non-stress environments in sub-Saharan Africa using marker-assisted recurrent selection. - Crop Science 56(1): 344353.

[7] Brune, P. F., Baumgarten, A., McKay, S. J., Technow, F., Podhiny, J. J. (2018): A biomechanical model for maize root lodging. - Plant and Soil 422(1-2): 397-408.

[8] Calvino, P. A., Andrade, F. H., Sadras, V. O. (2003): Maize yield as affected by water availability, soil depth and crop management. - Agronomy Journal 95(2): 275-281.

[9] Cambouris, A. N., Nolin, M. C., Zebarth, B. J., Laverdière, M. R. (2006): Soil management zones delineated by electrical conductivity to characterize spatial and temporal variations in potato yield and in soil properties. - American Journal of Potato Research 83(5): 381-395.

[10] Cassman, K. G., Dobermann, A., Walters, D. T. (2002): Agroecosystems, nitrogen-use efficiency, and nitrogen management. - AMBIO. - A Journal of the Human Environment 31(2): 132-140.

[11] Cerrato, M. E., Blackmer, A. M. (1990): Comparison of models for describing corn yield response to nitrogen fertilizer. - Agronomy Journal 82(1): 138-143.

[12] Chen, X., Cui, Z., Fan, M., Vitousek, P., Zhao, M., Ma, W., Deng, X. (2014): Producing more grain with lower environmental costs. - Nature 514(7523): 486.

[13] China Agriculture Database. (2017): Ministry of Agriculture of the People's Republic of China-Agriculture Database. - Beijing, China. http://zzys.agri.gov.cn.

[14] Cui, Z., Zhang, F., Mi, G., Chen, F., Li, F., Chen, X., Shi, L. (2009): Interaction between genotypic difference and nitrogen management strategy in determining nitrogen use efficiency of summer maize. - Plant and soil 317(1-2): 267-276.

[15] Doltra, J., Gallejones, P., Olesen, J. E., Hansen, S., Frøseth, R. B., Krauss, M., Pacini, G. C. (2019): Simulating soil fertility management effects on crop yield and soil nitrogen dynamics in field trials under organic farming in Europe. - Field Crops Research 233: 111 .

[16] Egamberdiyeva, D. (2007): The effect of plant growth promoting bacteria on growth and nutrient uptake of maize in two different soils. - Applied Soil ecology 36(2-3): 184-189.

[17] FAO. World Reference Base for Soil Resources (2006): World Soil Resources Reports. No.103.FAO, Rome.

[18] FAO. (2014): FAOSTAT-Agriculture Database. - Available at http://faostat.fao.org/ site/339/default.aspx.

[19] Farkhari, M., Krivanek, A., Xu, Y. B., Rong, T. Z., Naghavi, M. R., Samadi B. Y. (2013): Root-lodging resistance in maize as an example for high-throughput genetic mapping via single nucleotide polymorphism-based selective genotyping. - Plant Breeding 132(1): 9098.

[20] Fu, F. L., Feng, Z. L., Gao, S. B., Zhou, S. F., Li, W. C. (2008): Evaluation and Quantitative Inheritance of Several Drought-Relative Traits in Maize. - Agricultural Sciences in China 7(3): 280-290.

[21] Gang, X., Hua, B. L., Yu, F. P., Tie, Z. Y., Xi, Y., Shi, X. X. (2019): Plastic film mulching combined with nutrient management to improve water use efficiency, production of rain-fed maize and economic returns in semi-arid regions. - Field Crops Research 231: 30-39.

[22] Gao, Q., Li, C. L., Feng, G. Z., Wang, J. F., Cui, Z. L., Chen, X. P. (2012): Understanding Yield Response to Nitrogen to Achieve High Yield and High Nitrogen Use Efficiency in Rainfed Corn. - Agronomy journal 104(1): 165-168.

[23] He, J., Li, H. W., Gao, H. W. (2006): Subsoiling effect and economic benefit under conservation tillage mode in northern China. - CSAE 22: 62-67. (in Chinese). 
[24] Horowitz, W., Chichilo, P., Reynolds, H. (1970): Official methods of analysis of the Association of Official Analytical Chemists. - Washington, DC.

[25] Iqbal, J., Necpalova, M., Archontoulis, S. V., Anex, R. P., Bourguignon, M., Herzmann, D., Castellano, M. J. (2018): Extreme weather-year sequences have nonadditive effects on environmental nitrogen losses. - Global change biology 24(1): e303-e317.

[26] Kim, H. C., Moon, J. C., Kim, J. Y., Song, K., Kim, K. H., Lee, B. M. (2017): Evaluation of Drought Tolerance using Anthesis-silking Interval in Maize. - The Korean Journal of Crop Science (한국작물학회지) 62(1): 24-31.

[27] Ladha, J. K., Pathak, H., Krupnik, T. J., Six, J., Kessel, C. (2005): Efficiency of fertilizer nitrogen in cereal production: Retrospects and prospects. - Advances in agronomy 87: $86-156$.

[28] Liu, Y., Wang, E., Yang, X., Wang, J. (2010): Contributions of climatic and crop varietal changes to crop production in the North China Plain, since 1980. - Global Change Biology 16(8): 2287-2299.

[29] Lory, J. A., Scharf, P. C. (2003): Yield goal versus delta yield for predicting fertilizer nitrogen need in corn. - Agronomy Journal 95(4): 994-999.

[30] Lu, X. J., Li, Z. Z., Bu, Q. G., Cheng, D. J., Duan, W. X., Sun, Z. H. (2014): Effects of rainfall harvesting and mulching on corn yield and water use in the corn belt of Northeast China. - Agronomy Journal 106(6): 2175-2184.

[31] Lu, J., Bai, Z., Velthof, G. L., Wu, Z., Chadwick, D., Ma, L. (2019): Accumulation and leaching of nitrate in soils in wheat-maize production in China. - Agricultural water management 212: 407-415.

[32] Luce, M. S., Whalen, J. K., Ziadi, N., Zebarth, B. J. (2011): Nitrogen dynamics and indices to predict soil nitrogen supply in humid temperate soils. - Advances in agronomy 112: 55-102.

[33] Marjerison, R. D., Melkonian, J., Hutson, J. L., van Es, H. M., Sela, S., Geohring, L. D., Vetsch, J. (2016): Drainage and nitrate leaching from artificially drained maize fields simulated by the Precision Nitrogen Management model. - Journal of environmental quality 45(6): 2044-2052.

[34] McMaster, G. S., Wilhelm, W. W. (1997): Growing degree-days: One equation, two interpretations. - Agricultural and Forest Meteorology 87(4): 291-300.

[35] Meisinger, J. J. (1984): Evaluation plant available nitrogen in soil-crop system. - In: Hauck, R. D. (ed.) Nitrogen in Crop Production. ASA, CSSA, and SSSA, Madison, WI.

[36] Mesbah, M., Pattey, E., Jégo, G., Didier, A., Geng, X., Tremblay, N., Zhang, F. (2018): New model-based insights for strategic nitrogen recommendations adapted to given soil and climate. - Agronomy for Sustainable Development 38(4): 36.

[37] Qin, H. L., Gao, W. S., Ma, Y. C., Ma, L. (2008): Effects of subsoiling on soil moisture under conservation tillage mode. - Agric. Sci. China 41: 78-85. (in Chinese).

[38] Ray, D. K., Mueller, N. D., West, P. C., Foley, J. A. (2013): Yield Trends Are Insufficient to Double Global Crop Production by 2050. - PLoS ONE 8(6): e66428.

[39] Saini, H. S., Westgate, M. E. (2000): Reproductive development in grain crops during drought. - Advances in agronomy 68: 59-96.

[40] SAS Institute (1993): SAS User's Guide, Statistics. - SAS Inst., Cary, NC.

[41] Smith, J. L. (2018): Cycling of nitrogen through microbial activity. - Soil Biology: 97126. CRC Press.

[42] Tan, D. S., Jin, J. Y., Huang, S. W. (2007): Effect of Long-term Application of K Fertilizer on Spring MaizeYield and Soil K in Northeast China. - Scientia Agricultura Sinica 40(10): 2234-2240.

[43] Tao, Z. Q., Chen, Y. Q., Chao, L. I., Zou, J. X., Peng, Y., Yuan, S. F., Peng, S. (2016): The causes and impacts for heat stress in spring maize during grain filling in the North China Plain-A review. - Journal of integrative agriculture 15(12): 2677-2687. 
[44] Tesfaye, K., Gbegbelegbe, S., Cairns, J. E., Shiferaw, B., Prasanna, B. M., Sonder, K., Robertson, R. (2015): Maize systems under climate change in sub-Saharan Africa: Potential impacts on production and food security. - International Journal of Climate Change Strategies and Management 7(3): 247-271.

[45] Tolk, J. A., Howell, T. A., Evett, S. R. (1999): Effect of mulch, irrigation, and soil type on water use and yield of maize. - Soil \& Tillage Research 50(2): 137-147.

[46] Xie, J. G., Wang, L. C., Yin, C. X., Hou, Y. P., Zhang, G. H., Yu, L. (2008): Response to Fertilization of Maize on the Different Types of Soil in Jilin Province. - Journal of Maize Sciences 16(4): 167-171. (in Chinese).

[47] Yao, Z. F., Yang, F., Liu, X. T., Yan, M. H., Meng, J. (2011): Quantitative assessment of impacts of climate and economic-technical factors on grain yield in Jilin Province from 1980 to 2008. - Chinese Geographical Science 21(5): 543-553. (in Chinese).

[48] Zhang, X. Y., Wang, S. F., Sun, H. Y., Chen, S. Y., Shao, L. W., Liu, X. W. (2013): Contribution of cultivar, fertilizer and weather to yield variationof winter wheat over three decades: A case study in the North China Plain. - European journal of agronomy 50: $52-59$.

[49] Zhang, X., Xu, M., Sun, N., Xiong, W., Huang, S., Wu, L. (2016): Modelling and predicting crop yield, soil carbon and nitrogen stocks under climate change scenarios with fertiliser management in the North China Plain. - Geoderma 265: 176-186.

[50] Zhao, R. F., Chen, X. P., Zhang, F. S., Zhang, H., Schroder, J., Römheld, V. (2006): Fertilization and nitrogen balance in a wheat-maize rotation system in North China. Agronomy Journal 98(4): 938-945.

[51] Ziadi, N., Cambouris, A. N., Nyiraneza, J., Nolin, M. C. (2013): Across a landscape, soil texture controls the optimum rate of $\mathrm{N}$ fertilizer for maize production. - Field Crops Research 148: 78-85. 